\title{
Generalizability Appraisal of a Code-switching Scale in the Iranian ELT and Psychology Context: Examining the Role of Gender, Age, Proficiency and
}

\section{Educational Levels}

\author{
Zahra Mohammadi Salari', ${ }^{1}$ azlolah Samimi ${ }^{2}$, Shahram Afraz ${ }^{1}$ \\ 1. Department of English, Qeshm Branch, Islamic Azad University, Qeshm, Iran \\ 2. Department of English, Bandar-Abbas Branch, Islamic Azad University, Bandar-Abbas, Iran \\ * Corresponding author's Email: fazl.samimi67@gmail.com
}

\begin{abstract}
This quantitative study was an endeavor to generalize the findings of a qualitatively-oriented inquiry of code switching (CS). Therefore, in accordance with the themes and categories of the previous model, that is, 8 themes and 26 categories, a code switching survey consisting of 8 hypothetical factors and 43items was designed. Piloting the survey among 215 English as a Foreign Language (EFL) learners, it gained acceptable requirements for reliability and validity indices, except for the loading of 4 items that were discarded in the final version of the survey. Subsequently, the 39 item Likert-scale survey was distributed among 418 undergraduate and postgraduate ELT students chosen based on convenient sampling. To verify the factor structure of the instrument, structural equation modeling (SEM) was used which verified good fit indices. In addition, the findings showed that a tool for augmenting understanding was the most and teacher code switching as a barrier to learning and communication was the least influential factor of CS. Besides, Besides, the results indicated that all the demographic variables (age, gender, language proficiency, and educational level) except age had significant roles in the overall selection of code switching factors. Also, findings of this study could make it easier for the specialists in the field of educational psychology to fill the gaps of educational problems such as anxiety. So, the results of this study could help the ELT classroom to be a non-threatening place. Finally, it can be implicated that the model can be used in educational settings because it can help both students and teachers to achieve their pedagogic goals.
\end{abstract}

Keywords: Code-switching, Validation, EFA, CFA, SEM

\section{Introduction}

Today, globalization is perceived as one reason why people prefer bilingualism over monolingualism and the fact cannot be refuted that majority of people around the world are becoming bilinguals. Bilingualism means learning a second/foreign language fluently in addition to ones' native language to decrease misunderstandings and increase understanding (Zaim \& Escobar, 2011). Equally important are English classes where EFL learners and teachers use a combination of two languages and resort to certain strategies to make communication more effective and meaningful. One strategy is code switching. Wardhaugh (2006) expressed that code switching (henceforth, CS) is a significant strategy about which scholars can inquire thanks to the use of CS by bilingual and multilingual speakers. In other words, code switching is a prevalent practice in bilingual communities and Bullock and Toribio (2009) in general, 
defined CS as the ability of bilinguals to exchange easily between two languages. In addition, Lin (2013), in particular, explained that CS is a practice of using two languages in educational settings among teachers and students which is most often observed in second or foreign language classes.

In spite of the fact that CS has been extensively debated in recent years, scholars have not agreed thoroughly upon its practice in EFL classrooms. For instance, Cook (2001) states that teaching English through the medium of English is the best plan, while Nordin, Ali, Zubir, and Sadjirin, (2013) resort to CS to manage the flow of EFL classes and success of EFL learners. To further explicate the matter, Shin (2020) expressed that the reason for code switching maybe a lack of language knowledge, but many researchers believe that code switching is useful for bilinguals to fulfill communicative intentions.

In addition, scholars refer to sociolinguistic and psychological motivations behind the use of CS. Sebba (2012) asserted that the way bilinguals behave linguistically has informed many sociolinguists, psycholinguists, and linguists resulting in the creation of limitless doctrines for this phenomenon. While linguists focus on the form of code switching, according to sociolinguists such as Auer (2013) and Hawazen (2012), the major reason for code switching is its social function. In other words, speakers use code switching to fill the distance in a conversation with other participants. Moreover, Vogt (1954, p. 368) as a psycholinguist stated that "code-switching in itself is perhaps not a linguistic phenomenon, but rather a psychological one, and its causes are obviously extralinguistic.” As Javier and Marcos (1989) stated that stress influences language learners' performance psychologically and cognitively. It is important to know the role of stress in transferring linguistic knowledge.

To understand the effects of CS on teaching and learning processes, decades of research have focused on $\mathrm{CS}$ accentuating it as a disputable phenomenon that can have both positive and negative outcomes in the educational setting. From the positive side, Enama (2016) asserted that employing L1 is useful in the classroom because it activates the prior knowledge, and Peregoy and Boyle (2013) discussed that it can improve teaching and learning procedures because students can speak more clearly. On the flip side, Brown (2006) believed that using native language in the classroom is a sign of competence deficiency. Yet, the use of CS in non-native English classrooms is inevitable because the delivery of information in English may not lead to learning outcomes on the part of students, and L1 can fill the learning gaps and consolidate the ideas.

To-date, in spite of the fact that, an array of scholars have worked on the topic of CS in general (Alenezi, 2016; Ahmad \& Jussef, 2009; Azlan \& Narasuman, 2013; Bolander, 2008; Grobler, 2017; Ghafar Samar \& Moradkhani, 2014; Hobbs \& Matsuo, 2010; Rahimi \& Jafari, 2011; Rasouli \& Simin, 2015; Rezaee and Fathi,2016) and have become more involved with pros and cons of using L1 while teaching in EFL classrooms, few or no Iranian CS surveys exclusive to English Language Teaching(ELT) have been domestically developed and validated to inquire about the attitudes of ELT students . Therefore, this study aims to check the generalizability of a grounded theory study of CS by Mohammadi Salari, Samimi, and Afraz (2019) in terms of a quantitative model building and validated survey. 


\section{Literature Review}

It is quite likely in EFL classes that teachers may resort to more than one code to make the pedagogical duties accomplished, that is, being a conscious or unconscious behavior in the classroom, CS might have certain functions. Sert (2005) found that teachers change codes to discern different functions such as topic shift, indicating feelings, and for clarification. Also, Ferguson (2003) proposed a 3-category model of CS functions that consists of (a) CS for the purpose of understanding the subject matter, (b) CS for controlling the classroom, admiring learners, and gaining and maintaining leaners' attention, and (c) CS for discussing unrelated topics to teaching, social and interpersonal interactions, and classroom participation. In another study, Myers-Scotten (1993) classified CS in educational settings based on the markedness model. Hence, the components of the model are (a) CS for the elucidation of the subject, (b) CS to assess students' comprehension, (c) CS for better classroom management, and (d) CS for the purpose of humor in the classroom. Furthermore, Adendroff (1993) studied functions of CS in three high school classrooms, based on his findings, the first function of CS was building up learners' understanding of the subject matter and the second function was to help learners interpret it. In addition, Setati, Adler, Reed and Bapoo (2002) explored the role of CS in mathematics and science classes. The functions introduced by Setati et al. (2002) were CS as a pedagogic strategy and CS as a tool for understanding concepts and ideas. Besides, Arthur (2001) conducted a study on CS in a primary school in Botswana. He investigated the functions of CS in two grade-six classes. The findings showed CS as a useful tool for classroom management and encouraging classroom participation. Also, Rose and Dulm (2007) conducted a study on high school girls of Western Cape Province of South Africa. Their findings indicated that CS can help students and teachers build rapport.

Moreover, Liebscher and Dailey-O'Cain (2005) thought that teachers should persuade code-switching rather than avoiding its use in English classes. They also suggested that teachers should perceive codeswitching as a privilege that is encouraging and meaningful in order to inspire L2 acquisition. They stated that while code-switching is inevitable in foreign language classrooms, it is not likely to find L2 classrooms that permit and encourage their language learners to use L1. Moreover, they argued that there are some norms that dictate that L1 has no place in L2 classes. In fact, they pointed out to teachers' preferences to avoid L1 despite the fact that it can be highly encouraging and persuasive in certain cases. In other words, Heredia and Brown (2005, p.214) stated that "people often do CS in order to be understood better. Furthermore, Ghaffar Samar and Moradkhani's (2014) findings referred to students' comprehension of the information presented to them as the basic premise behind the applicability of CS. A review of the majarity of studies focused on code switching (Modupeola, 2013, Qian, Tian \& Wang, 2009, Lin, 2004, Momenian \& Samar, 2011) shows that teachers usually use students' native language for translation, more comprehension, controlling classroom, and built rapport with students.

On the other hand, according to Wei and Martin (2009), CS has been considered inappropriate in pedagogic classes, yet, it is perceived naturally in social contexts. In spite of the fact that many positive attributes can be attached to the use of L1, some scholars seem to label negative qualities to CS in L2 classrooms regardless of the fact that proficiency of EFL learners may play a key role in receiving such 
positive and negative attitudes. Therefore, Rezaee and Fathi (2017) considered the role of CS among EFL learners of various proficiency levels in Tehran, Iran. Having distributed a CS questionnaire among 105 language learners from the University of Tehran Language Center, they figured out that while elementary learners appealed teachers' CS behavior, students of higher proficiency levels opted for English-only instructions in their classes.

In the same vein, Mirhasani and Jafarpour Mamaghani (2009) conducted an experimental study to weigh the effectiveness of CS as a communicative strategy among low intermediate EFL learners in Karaj. Results indicated positive signs of early oral proficiency among lower intermediate EFL learners. Also, Hussien (1999) asserted that psychological reasons cause learners to code switch. One of them is lack of equivalents. Besides, Rasouli and Simin (2016) did a mixed-methods study about perceptions of intermediate EFL learners about CS at the aviation training center of Isfahan, Iran. Data were elicited from forty-three Intermediate EFL learners and seven teachers on a five-point Likert-scale questionnaire, and the follow up-in-depth interviews. The results pointed out to negative perceptions of students as to the employment of CS.

As a result, to address the controversies surrounding the use of CS and proficiency which was realized as a determining factor in general English classes in Iran (Mirhanssani \& Jafarpour, 2016, Rasooli \& Simin, 2016, Rezaian \& Fathi, 2017), later, a model of EFL high and low achievers' perspectives towards the limitations and benefits of teacher code switching in the context of Iranian ELT students was proposed by Mohammadi Salari, Samimi and Afraz (2019. In their qualitative study which was carried out using face to face and focus-group interviews, 11 high and 13 low achievers from different universities participated. Besides interviews, a course such as Linguistics, Teaching Methodology and Language Testing at B.A level from Bandar Abbas Aviation Industry University, Islamic Azad University of Bandar Abbas as well as Hormozgan University were observed. The findings indicated a model of limitations and benefits of code switching derived from the perceptions and practices of high and low achievers which consisted of 8 main themes ( 4 for high achievers \& 4 for low achievers) and 26 categories. The emerging themes for high achievers include (a) code switching as a barrier for learning and communication, (b) reliance upon subject matter, (c) further clarification v.s classroom management, and (d) rapport enhancing. Low achievers' themes, however, are (a) a tool for augmenting understanding, (b) obligatory for all topics and skills, (c) enhancing classroom participation, and (d) feeling of security. As a matter of fact, although diverse previous studies on the topic of code switching were reviewed above, a gap seems to have prevailed among the studies done in the context of Iranian EFL learners. Put it differently, the literature has partly failed to provide a CA scale/ questionnaire in the discipline of TEFL that has been locally developed and validated taking into account the voices of high and low achievers which seems to be important predicators according to which, the researchers believe code switching should be set in the classroom. As a result, this study further expands the previous model of code switching proposed by Mohammadi Salari, et.al, (2019) which is a qualitative study and its generalizability is under question. In other words, this study aims to validate a locally proposed model of CS to be used in the context of Iranian EFL learners instead of available scales in the literature which 
are based on the conditions of western countries, and not good choices for Iranian ELT students. Therefore, based on the above deficiencies, this study aimed to answer the following quantitative questions:

1. Through the use of SEM, does the designed scale according to the premises of Mohammadi Salari, et.al (2019) enjoy a good level of fit indices??

2. What are the most and the least code switching factors according to the attitudes of participants?

3. Are there any statistically significant differences among students of various genders, age groups, education and proficiency levels in terms of overall CS preferences?

\section{Method}

To validate a qualitative model of ELT high and low achievers' perspectives toward the limitations and benefits of teacher code switching, this study, expands upon a previous study carried out by Mohammadi Salari et al. (2019). Hence, the purpose of this study is to build a new CS instrument and in turn, check its generalizability in the Iranian context. In so doing, items of the questionnaire were taken from the qualitative model of ELT high and low achieves' perspectives toward the limitations and benefits of teacher code switching.

As a result, by the help of English experts to check the content and language of the items, a 43-item questionnaire of ELT students' attitudes toward code switching was designed based on the 8 factors of the model and its 26 categories. The questionnaire involved eight factors (see Table 1). The factors include (a) code switching as a barrier for communication (items 1,2,4,5,7,8,\& 10), (b) reliance upon subject matter (items 11,13,14,16, 17 \&19), (c) further clarification v.s classroom management (items $20,22,23,25,26, \& 28$ ), (d) rapport enhancing (items 29,31, 32, 33, 35, $27 \& 38$ ), (e) augmenting understanding (items 3, 6, 9, 12, \& 15), (f) obligatory for all topics and skills (items 18, 21 \& 24), (g) enhancing classroom participation (items $27,30,34 \& 36$ ), and (h) feeling of security (items 39, 40, $41,42,43)$. The Table below summarizes the items of the CS questionnaire.

Table 1. ELT Code Switching Questionnaire, Pilot Test

\begin{tabular}{|lc|}
\hline Factors & Items \\
\hline Code switching as a barrier for communication & $1,2,4,5,7,8 \& 10$ \\
Reliance upon subject matter & $11,13,14,16,17 \& 19$ \\
Further clarification v.s classroom management & $20,22,23,25,26, \& 28$ \\
Rapport Enhancing & $29,31,32,33,35,27 \& 38$ \\
Augmenting understanding & $3,6,9,12, \& 15$ \\
Obligatory for all topics and skills & $18,21 \& 24$ \\
Enhancing classroom participation & $27,30,34 \& 36$ \\
Feeling of security & $39,40,41,42,43$ \\
\hline
\end{tabular}




\section{Pilot Phase}

The next step after designing the questionnaire was to check its reliability and validity. For this purpose, the questionnaire was distributed among university students through a web-based survey, because online surveys do not have additional expenses and are easy to score and analyze. Also, to check the fairness of the sample size, it is suggested that any $N$ (the number of the cases) more than $200, N>200$ provides enough statistical power for data analysis (Hoe, 2008). Others recommend that five cases are enough for each item (Tabacknik \& Fidell 2007). Concerning the instrument used in this study, the ratio of the cases to items was about 5 to 1 (215 cases and 43 items) which may be regarded as suitable.

In order to check the reliability of the questionnaire, the Chronbach Alpha index was applied. This index is highly useful to show the scale's internal consistency (Pallant, 2010). As Pallant (2007, p, 95) stated "the degree to which the items of a scale hang together" is known as internal consistency. Cronbach's alpha coefficient for this study was 0.82 . As a result, the scale is reliable enough for the rest of the study. After checking the content validity of the items by three experts, the next step was to check the construct validity of the scale, according to Walden (2012), construct validity refers to whether the operational definition of a variable actually shows the underlying notion. In other words, the degree to which a test measures what it purports to be measuring. Verifying the construct validity of a scale can be done through a statistical procedure known as factor analysis, there are two types of factor analyses: Exploratory factor analysis (EFA) and Confirmatory factor analysis (CFA). In this study, exploratory factor analysis was used to explore the hidden variables of the questionnaire.

Examining the strength of how an item fits well with other items was done by a statistical procedure named communalities in exploratory factor analysis. Communalities give information about how much of the variance in each item is explained. A communality is the extent to which an item correlates with all other items and as a good rule of thumb 0.5 is emphasized (Burton \& Mazeroll, 2011, Comery \& Lee 1992). Regarding this matter, the scale in this study enjoyed having a sufficient number of communality values greater than 0.5 except for three questions (items, $15,18,29)$ which were cast aside.

So, as Pallant (2007) stated, for the factorability of the data, they might also be examined via a statistical test called Bartlett's test of sphericity (Bartlett, 1954) which should be significant $(p<0.05)$ and the Kaiser-Meyer-Olkin (KMO) measure of sampling adequacy with 0.6 recommended as the least value for good factor analysis, ( Tabanick \& Fidell, 2007). In this study, KMO was 0.904 which is greater than 0.6 and Bartlett's test was less than $0.5(\mathrm{sig}=0.000)$. Hence, these results confirm the appropriateness of the data in the scale.

Pallant (2007) recommends different ways to examine the satisfactory number of factors to reach. The first method is Kaiser's criterion or the eigenvalue cut-off point in which only factors whose eigenvalues are equal or more than 1.0 are kept. The results of the principal component analysis of this study revealed nine factors having eigenvalues $\geq 1.0$. The ninth factor was decided to be dropped from the 43 items questionnaire because it included only one item and it did not have a considerable amount as the other factors. 
Out of the remaining 42 items, 3 items failed to achieve the previous requirements. As a result, each item had proper loading only on one factor which, verifies that the scale in this study accurately measures what it was supposed to measure. The factor loadings for the 39 items are presented. To identify which items load on which components, the researchers looked for the highest loadings. After examining and verifying the reliability and validity of the CS constructed questionnaire, it was the right time to disseminate it among a large sample for the main section of this study.

Table 2. Pattern of Factor Loading

\begin{tabular}{|c|c|c|c|c|c|c|c|c|c|}
\hline & & \\
\hline \multirow[t]{2}{*}{ Item } & \multicolumn{9}{|c|}{ Component } \\
\hline & 1 & 2 & 3 & 4 & 5 & 6 & 7 & 8 & 9 \\
\hline 1 & .741 & & & & & & & & \\
\hline 2 & .425 & & & & & & & & \\
\hline 3 & & & & & .557 & & & & \\
\hline 4 & .764 & & & & & & & & \\
\hline 5 & .560 & & & & & & & & \\
\hline 6 & & & & & .503 & & & & \\
\hline 7 & .590 & & & & & & & & \\
\hline 8 & .698 & & & & & & & & \\
\hline 9 & & & & & .719 & & & & \\
\hline 10 & .589 & & & & & & & & \\
\hline 11 & & & & & & & & & .546 \\
\hline 12 & & & & & .674 & & & & \\
\hline 13 & & .633 & & & & & & & \\
\hline 14 & & .413 & & & & & & & \\
\hline 16 & & .603 & & & & & & & \\
\hline 17 & & .681 & & & & & & & \\
\hline 19 & & .586 & & & & & & & \\
\hline 20 & & & .508 & & & & & & \\
\hline 21 & & & & & & .528 & & & \\
\hline 22 & & & .753 & & & & & & \\
\hline 23 & & & .498 & & & & & & \\
\hline 24 & & & & & & .708 & & & \\
\hline 25 & & & .719 & & & & & & \\
\hline 26 & & & .578 & & & & & & \\
\hline 27 & & & & & & & .631 & & \\
\hline 28 & & & .559 & & & & & & \\
\hline 30 & & & & & & & .674 & & \\
\hline 31 & & & & .732 & & & & & \\
\hline 32 & & & & .549 & & & & & \\
\hline 33 & & & & .711 & & & & & \\
\hline 34 & & & & & & & .675 & & \\
\hline 35 & & & & .395 & & & & & \\
\hline 36 & & & & & & & .624 & & \\
\hline 37 & & & & .630 & & & & & \\
\hline 38 & & & & .512 & & & & & \\
\hline 39 & & & & & & & & .681 & \\
\hline 40 & & & & & & & & .755 & \\
\hline 41 & & & & & & & & .679 & \\
\hline 42 & & & & & & & & .520 & \\
\hline 43 & & & & & & & & .438 & \\
\hline
\end{tabular}




\section{Participants}

Because the sample needed to be large, convenient sampling was used. The participants in this strand of the study consisted of 418 EFL undergraduate and postgraduate ELT learners studying at different Islamic Azad universities as well as state universities from all around Iran. The sample included 181 males and 237 females. For ethical purposes of the study, at beginning of the questionnaire, the researchers explained the aim of the study to the participants and assured them that their personal information would be kept confidential and the results of the study would be used only for educational purposes.

\section{Materials and Instruments}

The instrument used in the study is the ELT CS questionnaire which the process of its validation was explained earlier. The validated instrument consists of 39 items and demographic information (age, gender, educational level, purported Language proficiency). Three Scholars in the field of educational psychology confirmed that questions number $15,23,35,37$ of the scale were in the scope of educational psychology.

\section{Data Collection Procedures}

At this stage, the validated CS questionnaire was disseminated among 418 ELT students to tap into their attitudes regarding CS factors and items. In fact, the questionnaire was distributed among students through a web-based format made in Google Doc, because online scales are easy to spread and are less costly. Consequently, during the academic semester of winter and spring of 2019, the researchers went to Islamic Azad universities of Kerman and Bandar Abbas and also state universities of Kerman and Bandar Abbas to share the survey link among students and to ask the students to share it with their friends and classmates via social networks such as Whats app and Telegram. Likewise, the researchers asked their colleagues to share it among their students as well. In so doing, the questionnaire's link was copied and sent to as many students from all around Iran. As a result, the researchers checked the Google form on a daily basis to see how many students had filled the form. Overall, after 1 month, the number of answered surveys reached 418 which was a sufficient number for data analysis and interpretation.

\section{Data analysis}

The key goal of this study was to appraise the generalizability of a newly-developed survey of CS in the context of Iranian ELT university students. To meet this end, Structural Equation Modeling (SEM) was used. The SEM is a powerful statistical technique that aims to evaluate and define the main factors and also to appraise the relationship among the factors and items. In order to find out the effect of gender on overall CS, independent-samples t-test was applied. In addition, to spot the effect of different age groups on code switching, one-way ANOVA was used. Moreover, the analysis of variance (ANOVA) was used to test the effect of students' level of education and language proficiency on the overall CS.

\section{Results}

Confirmatory Factor Analysis to Check Fit IndicesTo scrutinize the plausibility of the model of ELT students' perspectives toward teacher code switching and to determine the relationship between the latent 
and observed variables, the confirmatory factor analysis (CFA) was applied using structural equation modeling (SEM). In fact, "CFA is used to examine the fairness of fit of one or more hypothesized factor models of a measure" (Adelheid \& Penny, 2012, p.127). Regarding this study, eight measurement indices were introduced and their goodness of fit must be checked. CFA was run through LISREL software. Figure 1 indicates the path diagram of the suggested model:

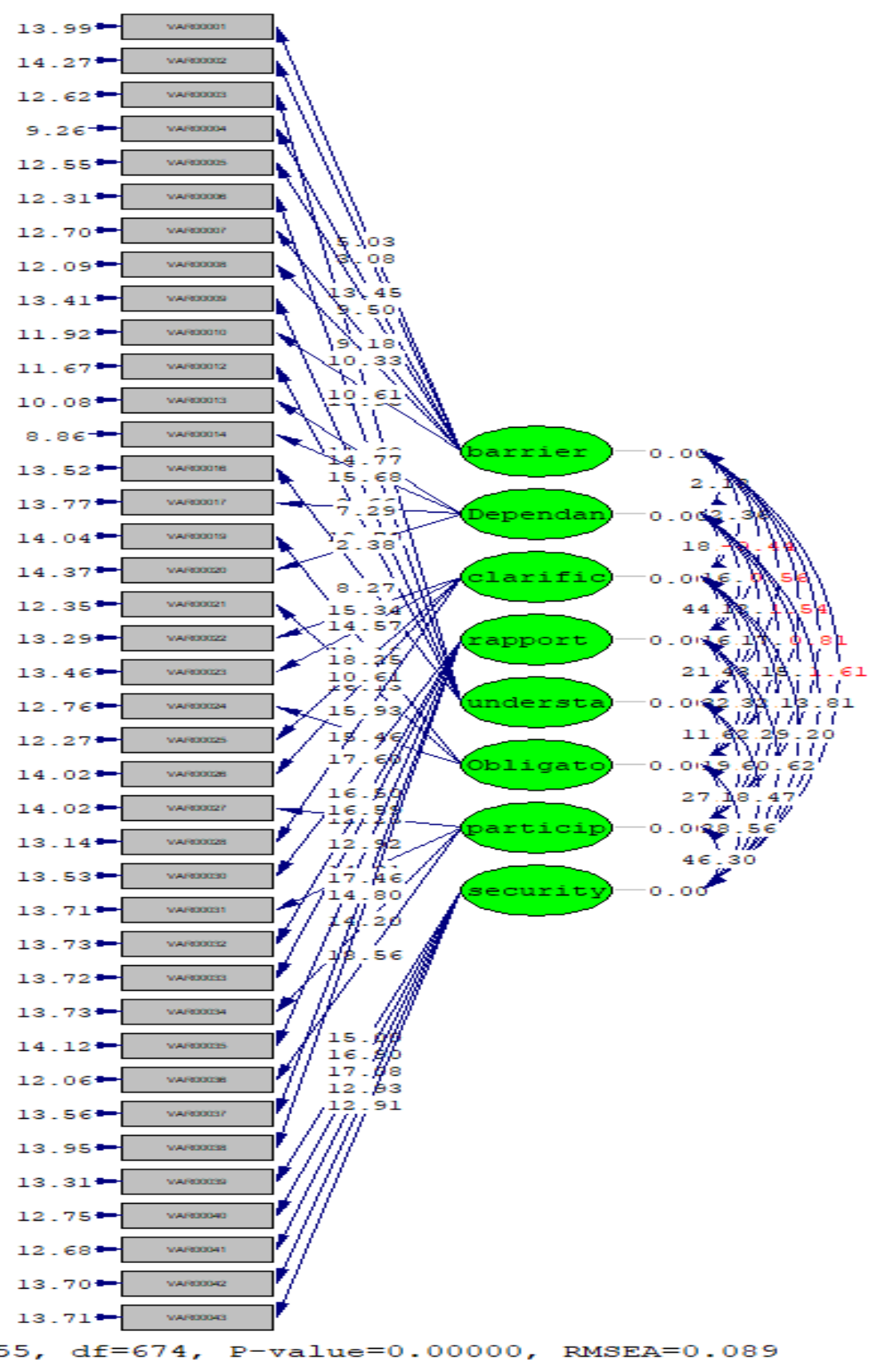

Figure 1. The Path Diagram of CS Model 
There is a wide range of fit indices, because there is no single yardstick to check the theoretical model fit evaluation acquired from SEM (Ding, Velicer, Harlow, 1995; Schermelleh-Engel \& Moosbrugger 2003; Sugawara \& MacCallum 1993). For model appraisal, fit indices were checked. The first index is RMSEA, which is the population root mean square error of approximation. The recommended cut-off points for RMSEA are $<0.08$ which is considered a good fit, between 0.08 and 0.1 indicates adequate fit, and $>0.1$ shows poor fit (Kenny et.al, 2014). In this model, as it is noticeable in Table 4, RMSEA is 0.8 . The next index is the comparative fit index (CFI) considered acceptable with the values larger than 0.90. In this study (CFI) value is 0.93 . In addition, the next index is (IFI) whose normal fit index should exceed 0.90 (Schumacker \& Lomax, 2004). In this study, the value of IFI is 0.93 . The other fit indices are normal fit index (NFI) and non- normal fit index (NNFI) which should be over 0.9 for a good fit (Bentler, 1990). In this study these values are 0.91 and 0.92 respectively.

Table3. The Obtained and the Acceptable Values of the Fit Indices

\begin{tabular}{|l|l|l|l|l|l|}
\hline Fit indices & RMSEA & CFI & IFI & NFI & NNFI \\
\hline The obtained value & 0.89 & 0.93 & 0.93 & 0.91 & 0.92 \\
\hline The acceptable value & $<0.1$ & $>0.90$ & $>0.90$ & $>0.90$ & $>0.90$ \\
\hline
\end{tabular}

The above findings indicate that all the fit indices lie within the acceptable fit criterion. Therefore, it can be inferred that the presented model had a good fit with the data. The goodness and validity of the proposed model were also verified. Hence, this model can be a reliable source for Iranian researchers who are exploring for a valid localized model of limitations and benefits of code switching in the context of Iran.

\section{The Most and the Least Influential Factor}

In order to identify the most and the least significant factors in relation to code switching preferences, the mean scores of ELT students' responses to the underlying factors were calculated in the order of significance as follows:

Table 4. The Eight Factors of CS in the Order of Significance

\begin{tabular}{|l|l|l|l|l|l|}
\hline & $\mathrm{N}$ & Minimum & Maximum & Mean & SD \\
\hline A tool for augmenting understanding & 418 & 1.00 & 5.00 & 3.4916 & .70981 \\
\hline Feeling of security & 418 & 1.20 & 5.00 & 3.2593 & .74404 \\
\hline A tool to build rapport & 418 & 1.00 & 5.00 & 3.2504 & .74663 \\
& & & & \\
\hline Enhancing classroom participation & 418 & 1.25 & 5.00 & 3.2440 & .78293 \\
\hline A tool for clarification and classroom management & & & & \\
\hline Dependency on subject matter & 418 & 1.17 & 2.00 & 3.1308 & .66339 \\
\hline Obligatory for all topics (skills) & 418 & 1.20 & 5.00 & 3.0373 & .73105 \\
\hline Teachers' code switching as a barrier for communication & 418 & 1.43 & 5.00 & 2.9211 & .91863 \\
\hline
\end{tabular}

As table 4 shows, "A tool for augmenting understanding" with a mean score of 3.49 , and the least significant factor was "teachers" code switching as a barrier for communication" with a mean score of 2.78 . 


\section{Descriptive findings related to demographic information}

To determine the effect of age on overall CS factors, an independent sample t-test was run as follows:

Table 5. The Independent Sample T-Test

\begin{tabular}{|l|l|l|l|l|l|l|l|}
\hline & Gender & $\mathrm{N}$ & Mean & SD & Std. Error Mean & $\mathrm{T}$ & $p$ \\
\cline { 1 - 8 } Overall Code switching Factors & Male & 181 & 3.1438 & .57234 & .04254 & 2.756 & \multirow{2}{*}{.001} \\
\cline { 2 - 7 } & Female & 237 & 3.1365 & .56119 & .03645 & & \\
\hline
\end{tabular}

The results showed the effect of gender on the selection of code switching factors. $p$ value $=.001$ is smaller than .05 which means there is a significant difference between males and females' preferences for selecting of the overall code switching factors.

To discover the effects of age, language proficiency, and educational level on the latent variables, analysis of variances (ANOVA) was applied. Regarding the effect of age on the code switching preferences, findings were not promising.

Table6. ANOVA Results for Age

\begin{tabular}{|c|c|c|c|c|c|c|}
\hline & & $\mathrm{N}$ & Mean & Std. Deviation & $\mathrm{F}$ & $p$ \\
\hline \multirow[t]{4}{*}{ Overall Code switching Factors } & under 20 & 53 & 3.2421 & .51752 & \multirow[t]{4}{*}{1.127} & \multirow[t]{4}{*}{.325} \\
\hline & $20-30$ & 208 & 3.1379 & .56687 & & \\
\hline & above 30 & 157 & 3.1074 & .57806 & & \\
\hline & Total & 418 & 3.1396 & .56538 & & \\
\hline
\end{tabular}

As it is noticeable in Table 5, there are no significant differences among the three age ranges (under 20, 20-30, and above 30 ). Sig $=.325$ is greater than .05 . Hence, it can be deduced from the above table that age does not have any effect on the selection of code switching factors by the learners in this study. In addition, the effect of language proficiency of ELT students on different proficiency levels was tested as follows:

Table 7. ANOVA Results for Language Proficiency

\begin{tabular}{|l|l|l|l|l|l|l|}
\hline \multicolumn{2}{|c|}{} & N & Mean & Std. Deviation & F & Sig. \\
\hline \multirow{2}{*}{$\begin{array}{l}\text { Overall Code } \\
\text { Switching Factors }\end{array}$} & ELEMENTARY & 34 & 3.0717 & .56865 & & \\
\cline { 2 - 6 } & INTERMEDIATE & 153 & 3.1582 & .56763 & \multirow{2}{*}{3.546} & .027 \\
\cline { 2 - 6 } & ADVANCED & 231 & 3.1373 & .56506 & & \\
\cline { 2 - 6 } & Total & 418 & 3.1396 & .56538 & & \\
\hline
\end{tabular}

A close examination of ANOVA in Table 6 indicates that sig $=.027$ is smaller than 0.05 which means there are significant differences among the proficiency levels and preferences toward selecting code switching factors. Due to reaching statistical significance, post-hoc comparisons using Tukey HSD test indicated that there was a significant difference between elementary and other language proficiencies in relation to code switching factors because sig was less than 0.05 . 
Table 8. Tukey HSD for language proficiency

\begin{tabular}{|c|c|c|c|c|c|c|c|}
\hline \multicolumn{8}{|c|}{ Multiple Comparisons } \\
\hline \multicolumn{8}{|l|}{ Tukey HSD } \\
\hline \multirow{2}{*}{$\begin{array}{l}\text { Dependent } \\
\text { Variable }\end{array}$} & \multirow[t]{2}{*}{ (I) Poficiency } & \multirow[t]{2}{*}{ (J) Poficiency } & \multirow{2}{*}{$\begin{array}{l}\text { Mean Difference } \\
(\mathrm{I}-\mathrm{J})\end{array}$} & \multirow{2}{*}{$\begin{array}{l}\text { Std. } \\
\text { Error }\end{array}$} & \multirow[t]{2}{*}{$p$} & \multicolumn{2}{|c|}{$95 \%$ Confidence Interval } \\
\hline & & & & & & $\begin{array}{l}\text { Lower } \\
\text { Bound }\end{array}$ & $\begin{array}{l}\text { Upper } \\
\text { Bound }\end{array}$ \\
\hline \multirow[t]{6}{*}{ Factor 1} & \multirow[t]{2}{*}{ ELEMENTARY } & INTERMEDIATE & -.01120 & .11372 & .005 & -.2787 & .2563 \\
\hline & & ADVANCED & .02059 & .11017 & .001 & -.2386 & .2797 \\
\hline & \multirow[t]{2}{*}{ INTERMEDIATE } & ELEMENTARY & .01120 & .11372 & .005 & -.2563 & .2787 \\
\hline & & ADVANCED & .03179 & .06252 & .867 & -.1153 & .1789 \\
\hline & \multirow[t]{2}{*}{ ADVANCED } & ELEMENTARY & -.02059 & .11017 & .001 & -.2797 & .2386 \\
\hline & & INTERMEDIATE & -.03179 & .06252 & .867 & -.1789 & .1153 \\
\hline \multirow[t]{6}{*}{ Factor 2} & \multirow[t]{2}{*}{ ELEMENTARY } & INTERMEDIATE & -.01634 & .13893 & .002 & -.3431 & .3105 \\
\hline & & ADVANCED & -.00349 & .13460 & .004 & -.3201 & .3131 \\
\hline & \multirow[t]{2}{*}{ INTERMEDIATE } & ELEMENTARY & .01634 & .13893 & .002 & -.3105 & .3431 \\
\hline & & ADVANCED & .01285 & .07638 & .985 & -.1668 & .1925 \\
\hline & \multirow[t]{2}{*}{ ADVANCED } & ELEMENTARY & .00349 & .13460 & .004 & -.3131 & .3201 \\
\hline & & INTERMEDIATE & -.01285 & .07638 & .985 & -.1925 & .1668 \\
\hline \multirow[t]{6}{*}{ Factor 3} & \multirow[t]{2}{*}{ ELEMENTARY } & INTERMEDIATE & -.10839 & .12595 & .005 & -.4046 & .1879 \\
\hline & & ADVANCED & -.06729 & .12203 & .006 & -.3543 & .2197 \\
\hline & \multirow[t]{2}{*}{ INTERMEDIATE } & ELEMENTARY & .10839 & .12595 & .005 & -.1879 & .4046 \\
\hline & & ADVANCED & .04110 & .06924 & .824 & -.1218 & .2040 \\
\hline & \multirow[t]{2}{*}{ ADVANCED } & ELEMENTARY & .06729 & .12203 & .006 & -.2197 & .3543 \\
\hline & & INTERMEDIATE & -.04110 & .06924 & .824 & -.2040 & .1218 \\
\hline \multirow[t]{6}{*}{ Factor 4} & \multirow[t]{2}{*}{ ELEMENTARY } & INTERMEDIATE & -.12255 & .14177 & .003 & -.4560 & .2109 \\
\hline & & ADVANCED & -.09696 & .13735 & .023 & -.4200 & .2261 \\
\hline & \multirow[t]{2}{*}{ INTERMEDIATE } & ELEMENTARY & .12255 & .14177 & .003 & -.2109 & .4560 \\
\hline & & ADVANCED & .02559 & .07794 & .942 & -.1577 & .2089 \\
\hline & \multirow[t]{2}{*}{ ADVANCED } & ELEMENTARY & .09696 & .13735 & .023 & -.2261 & .4200 \\
\hline & & INTERMEDIATE & -.02559 & .07794 & .942 & -.2089 & .1577 \\
\hline Factor 5 & ELEMENTARY & INTERMEDIATE & -.29657 & .13398 & .030 & -.6117 & .0186 \\
\hline & & ADVANCED & $-.30733^{*}$ & .12980 & .048 & -.6126 & -.0020 \\
\hline & INTERMEDIATE & ELEMENTARY & .29657 & .13398 & .030 & -.0186 & .6117 \\
\hline & & ADVANCED & -.01076 & .07365 & .988 & -.1840 & .1625 \\
\hline & ADVANCED & ELEMENTARY & $.30733^{*}$ & .12980 & .048 & .0020 & .6126 \\
\hline & & INTERMEDIATE & .01076 & .07365 & .988 & -.1625 & .1840 \\
\hline Factor 6 & ELEMENTARY & INTERMEDIATE & .03105 & .17458 & .013 & -.3796 & .4417 \\
\hline & & ADVANCED & .04246 & .16913 & .006 & -.3554 & .4403 \\
\hline & INTERMEDIATE & ELEMENTARY & -.03105 & .17458 & .013 & -.4417 & .3796 \\
\hline & & ADVANCED & .01142 & .09598 & .992 & -.2143 & .2372 \\
\hline & ADVANCED & ELEMENTARY & -.04246 & .16913 & .006 & -.4403 & .3554 \\
\hline & & INTERMEDIATE & -.01142 & .09598 & .992 & -.2372 & .2143 \\
\hline Factor 7 & ELEMENTARY & INTERMEDIATE & -.02614 & .14879 & .003 & -.3761 & .3238 \\
\hline
\end{tabular}




\begin{tabular}{|c|c|c|c|c|c|c|c|}
\hline & & ADVANCED & -.02508 & .14415 & .043 & -.3642 & .3140 \\
\hline & \multirow[t]{2}{*}{ INTERMEDIATE } & ELEMENTARY & .02614 & 14879 & .003 & -.3238 & 3761 \\
\hline & & ADVANCED & .00106 & .08180 & 1.000 & -.1913 & 1935 \\
\hline & \multirow[t]{2}{*}{ ADVANCED } & ELEMENTARY & .02508 & .14415 & .043 & -.3140 & .3642 \\
\hline & & INTERMEDIATE & -.00106 & 08180 & 1.000 & -.1935 & 1913 \\
\hline \multirow[t]{6}{*}{ Factor 8} & \multirow[t]{2}{*}{ ELEMENTARY } & INTERMEDIATE & -.14183 & 14121 & .035 & -.4740 & 1903 \\
\hline & & ADVANCED & -.08793 & 13681 & .007 & -.4097 & .2339 \\
\hline & \multirow[t]{2}{*}{ INTERMEDIATE } & ELEMENTARY & .14183 & 14121 & .035 & -.1903 & 4740 \\
\hline & & ADVANCED & .05390 & .07763 & .767 & -.1287 & .2365 \\
\hline & \multirow[t]{2}{*}{ ADVANCED } & ELEMENTARY & .08793 & 13681 & .007 & -.2339 & 4097 \\
\hline & & INTERMEDIATE & -.05390 & .07763 & .767 & -.2365 & .1287 \\
\hline
\end{tabular}

Finally, the effect of different educational levels of ELT students on CS preferences revealed statistical differences presented below:

Table 9. ANOVA Results for Educational Level

\begin{tabular}{|c|c|c|c|c|c|c|}
\hline & & $\mathrm{N}$ & Mean & Std. Deviation & $\mathrm{F}$ & $p$ \\
\hline \multirow{4}{*}{$\begin{array}{l}\text { Overall code } \\
\text { switching Factors }\end{array}$} & BACHELORE'S & 226 & 3.1359 & .56830 & \multirow[t]{4}{*}{2.970} & \multirow[t]{4}{*}{.012} \\
\hline & MASTER'S & 150 & 3.1125 & .56049 & & \\
\hline & DOCTORAL & 42 & 3.2569 & .56585 & & \\
\hline & Total & 418 & 3.1396 & .56538 & & \\
\hline
\end{tabular}

Checking the Table 9, the results revealed that sig $=.012$ is smaller than .05 which means there are significant differences among different educational levels of learners and their preferences for selecting code switching factors. As the result of reaching statistical significance differences, post-hoc comparisons using Tukey HSD test was run and showed a significant difference between Bachelors' and other educational levels in relation to code switching factors $(\mathrm{p}<.05)$.

Table 10. Tukey HSD for Educational Level

Multiple Comparisons

\begin{tabular}{|c|c|c|c|c|c|c|c|}
\hline \multicolumn{8}{|c|}{ Multiple Comparisons } \\
\hline \multicolumn{8}{|c|}{ Tukey HSD } \\
\hline \multirow{2}{*}{$\begin{array}{l}\text { Dependent } \\
\text { Variable }\end{array}$} & \multirow[t]{2}{*}{ (I) Education } & \multirow[t]{2}{*}{ (J) Education } & \multirow{2}{*}{$\begin{array}{c}\text { Mean } \\
\text { Difference (I-J) }\end{array}$} & \multirow{2}{*}{$\begin{array}{l}\text { Std. } \\
\text { Error }\end{array}$} & \multirow[t]{2}{*}{$p$} & \multicolumn{2}{|c|}{ 95\% Confidence Interval } \\
\hline & & & & & & $\begin{array}{l}\text { Lower } \\
\text { Bound }\end{array}$ & $\begin{array}{l}\text { Upper } \\
\text { Bound }\end{array}$ \\
\hline \multirow[t]{6}{*}{ Factor 1} & \multirow[t]{2}{*}{ BACHELORE'S } & MASTER'S & -.05426 & .06284 & .004 & .2021 & .3936 \\
\hline & & DOCTORAL & .16778 & .10027 & .017 & .0681 & .4036 \\
\hline & \multirow[t]{2}{*}{ MASTER'S } & BACHELORE'S & .05426 & .06284 & .004 & .2021 & .3936 \\
\hline & & DOCTORAL & .22204 & .10417 & .085 & -.0230 & .4671 \\
\hline & \multirow[t]{2}{*}{ DOCTORAL } & BACHELORE'S & -.16778 & .10027 & .017 & .0681 & .4036 \\
\hline & & MASTER'S & -.22204 & .10417 & .085 & -.4671 & .0230 \\
\hline \multirow[t]{5}{*}{ Factor 2} & \multirow[t]{2}{*}{ BACHELORE'S } & MASTER'S & -.00683 & .07717 & .006 & .1747 & .1884 \\
\hline & & DOCTORAL & .02288 & .12313 & .001 & .2667 & .3125 \\
\hline & \multirow[t]{2}{*}{ MASTER'S } & BACHELORE'S & .00683 & .07717 & .006 & .1747 & .1884 \\
\hline & & DOCTORAL & .02971 & .12792 & .971 & -.2712 & .3306 \\
\hline & DOCTORAL & BACHELORE'S & -.02288 & .12313 & .001 & .2667 & .3125 \\
\hline
\end{tabular}


Generalizability Appraisal of a Code-switching Scale in the Iranian ELT and Psychology Context...

\begin{tabular}{|c|c|c|c|c|c|c|c|}
\hline & & MASTER'S & -.02971 & .12792 & .971 & -.3306 & .2712 \\
\hline \multirow[t]{6}{*}{ Factor 3} & \multirow[t]{2}{*}{ BACHELORE'S } & MASTER'S & .01869 & .06995 & .001 & 1458 & .1832 \\
\hline & & DOCTORAL & -.09861 & .11160 & .001 & .0611 & .1639 \\
\hline & \multirow[t]{2}{*}{ MASTER'S } & BACHELORE'S & -.01869 & .06995 & .001 & .1458 & .1832 \\
\hline & & DOCTORAL & -.11730 & .11595 & .570 & -.3900 & .1554 \\
\hline & \multirow[t]{2}{*}{ DOCTORAL } & BACHELORE'S & .09861 & .11160 & .001 & .1639 & .3611 \\
\hline & & MASTER'S & .11730 & .11595 & .570 & -.1554 & .3900 \\
\hline \multirow[t]{6}{*}{ Factor 4} & \multirow[t]{2}{*}{ BACHELORE'S } & MASTER'S & .05740 & .07845 & .005 & .1271 & .2419 \\
\hline & & DOCTORAL & -.20164 & .12516 & .002 & .4960 & .5928 \\
\hline & \multirow[t]{2}{*}{ MASTER'S } & BACHELORE'S & -.05740 & .07845 & .005 & .1271 & .2419 \\
\hline & & DOCTORAL & -.25905 & .13004 & .115 & -.5649 & .0468 \\
\hline & \multirow[t]{2}{*}{ DOCTORAL } & BACHELORE'S & .20164 & .12516 & .002 & .4960 & .5928 \\
\hline & & MASTER'S & .25905 & .13004 & .115 & -.0468 & .5649 \\
\hline \multirow[t]{6}{*}{ Factor 5} & \multirow[t]{2}{*}{ BACHELORE'S } & MASTER'S & .01901 & .07444 & .005 & .1561 & .1941 \\
\hline & & DOCTORAL & -.25980 & .11878 & .005 & .0196 & .5392 \\
\hline & \multirow[t]{2}{*}{ MASTER'S } & BACHELORE'S & -.01901 & .07444 & .005 & -.1941 & .1561 \\
\hline & & DOCTORAL & -.27881 & .12340 & .063 & -.5691 & .0114 \\
\hline & \multirow[t]{2}{*}{ DOCTORAL } & BACHELORE'S & .25980 & .11878 & .005 & .0196 & .5392 \\
\hline & & MASTER'S & .27881 & .12340 & .063 & -.0114 & .5691 \\
\hline \multirow[t]{6}{*}{ Factor 6} & \multirow[t]{2}{*}{ BACHELORE'S } & MASTER'S & .03814 & .09679 & .008 & .1895 & .2658 \\
\hline & & DOCTORAL & -.16519 & .15443 & .033 & .1980 & .5284 \\
\hline & \multirow[t]{2}{*}{ MASTER'S } & BACHELORE'S & -.03814 & .09679 & .008 & .2658 & .1895 \\
\hline & & DOCTORAL & -.20333 & .16044 & .415 & -.5807 & .1741 \\
\hline & \multirow[t]{2}{*}{ DOCTORAL } & BACHELORE'S & .16519 & .15443 & .033 & .1980 & .5284 \\
\hline & & MASTER'S & .20333 & .16044 & .415 & -.1741 & .5807 \\
\hline \multirow[t]{6}{*}{ Factor 7} & \multirow[t]{2}{*}{ BACHELORE'S } & MASTER'S & .07836 & .08194 & .005 & .1144 & .2711 \\
\hline & & DOCTORAL & -.28640 & .13074 & .004 & .0211 & .5939 \\
\hline & \multirow[t]{2}{*}{ MASTER'S } & BACHELORE'S & -.07836 & .08194 & .005 & .1144 & .2711 \\
\hline & & DOCTORAL & $-.36476^{*}$ & .13583 & .121 & -.6843 & -.0453 \\
\hline & \multirow[t]{2}{*}{ DOCTORAL } & BACHELORE'S & .28640 & .13074 & .004 & .0211 & .5939 \\
\hline & & MASTER'S & $.36476^{*}$ & .13583 & .121 & .0453 & .6843 \\
\hline \multirow[t]{6}{*}{ Factor 8} & \multirow[t]{2}{*}{ BACHELORE'S } & MASTER'S & .03619 & .07836 & .009 & .2205 & .3481 \\
\hline & & DOCTORAL & -.14724 & .12502 & .007 & .0413 & .1468 \\
\hline & \multirow[t]{2}{*}{ MASTER'S } & BACHELORE'S & -.03619 & .07836 & .009 & .2205 & .3481 \\
\hline & & DOCTORAL & -.18343 & .12989 & .336 & -.4890 & .1221 \\
\hline & \multirow[t]{2}{*}{ DOCTORAL } & BACHELORE'S & .14724 & .12502 & .007 & .0413 & .1468 \\
\hline & & MASTER'S & .18343 & .12989 & .336 & -.1221 & .4890 \\
\hline
\end{tabular}

\section{Discussion}

This study, on the one hand, aimed to check the fit indices of the newly-developed CS scale in the Iranian ELT discipline. The findings showed the model enjoys fit indices and can be used as a new scale in the Iranian context passing rigorous statistical analyses that yielded warranty for its applicability. The final model of ELT code switching encompasses eight factors. If we look at the order of significance of factors, it can be easily spotted that ELT students have had positive attitudes towards CS. They have agreed that CS was a tool for augmenting understanding, due to the fact that English is regarded as a foreign language in the Iranian context and learners have problems with the English only classes in specialized courses. According to Adendroff (1993) learners believe that teacher code switching was a tool to gain and keep their attention toward the subject matter, which leads to a better understanding of the difficult concepts. 
Similarly, feeling of security is the second most important factor of the proposed model. This idea is advantageous to those learners who are anxious and hence CS makes them feel more relaxed in ELT classrooms. Admittedly, the classroom can turn into a non-threatening place that maximizes the learning potentials and minimizes the stress and anxiety among ELT students. The findings of this study are in congruent with the findings of Lightbowen and Spada (2011) who stated that those students who feels accepted, valued, confident, and safe in the classroom can be motivated to succeed.

Moreover, CS is a tool to build rapport. By the same token, teacher CS can be a suitable strategy for humor, increasing solidarity and cooperation in the ELT classrooms. The findings of this study are in congruent with the findings of Ferguson (2003) who asserted that the classroom is not entirely a place for learning; but it is also a social and affective environment. The fourth positive factor of the model was enhancing classroom participation. Code switching may be a reason for the academic achievements of shy and less willing to communicate ELT students because it encourages learners' participation. The results of this factor are congruent with the findings of Arthur (2001). The findings showed CS as a useful tool for classroom management and encouraging classroom participation.

Furthermore, a tool for task clarification and classroom management were the next factors of the code switching model. This factor indicates that code switching is a tool for classroom management. Teachers can control and discipline ELT classrooms by switching codes in Farsi. The results of this study are in line with those of Rose and Dulm (2007). So, code switching is a useful tool to be used by teachers for task interpretation. (Adendroff, 1993; Setati et al. 2002). Besides this, dependency upon the subject matter of the study as another factor of the model implies that for certain courses according to the knowledge and understanding of the level and difficulty of certain courses, instructors can switch codes to L1. As such, code switching is a useful tool for quick delivery of information in these subjects. The findings of the factor support the idea that code switching help learners to elucidate the subject matter (Roze \&Dulm, 2007; Setati \& Adler, 2000; Ferguson, 2003). Additionally, obligatory for all skills was the 7th factor of the presented model. That is to say, CS cannot be specified to only one skill and it can be used as teachers feel the need that they should switch codes in order to consolidate the matter under discussion.

The $8^{\text {th }}$ and the least favored factor of the model states that code switching by a teacher may impede learning the foreign language (Setati, et al. 2002). The results of the final factor indicate that code switching acts as a barrier to communication instead of making it easier. Sert (2005) stated that code switching creates problems in the classroom. He believed that if learners do not use the target language in the classroom, their deficiencies may be neglected, And Qian, Tian and Wang (2009) stated that code switching has changed to a complex issue since classroom communication is the main goal. Furthermore, Modupeola (2013) asserted that code switching assists learners to comprehend the teachers but it decreases the rate of learning. Equally important, according to Lin (2004) some teachers use L1 in the classroom because their knowledge about TL is not enough to transfer the message to the students.

This study, on the other, examined the role of gender, age, proficiency and educational levels on the overall CS preferences in a specialized course offered to TEFL students. With respect to gender, a 
significant difference between male and female ELT students was spotted. In other words, males opted more to use CS. This high tendency toward CS might be as Momenian and Ghafar Samar (2011) stated, because of male's loyalty to their mother tongue, and adding a humorous sense into their utterance. The findings of this study regarding the effect of gender are in line with what Cheshire and Gardner-Chloros (1998) stated as well. Also, age was found an insignificant factor regarding the attitudes of ELT students toward CS. The results negate Sumartono and Tan's (2018) study who found that younger speakers tend to use code switching more often than older speakers. The discrepancy of findings might be explicated on the grounds that Iranian ELT students might be different in terms of their psychological makeup from ones on other contexts.

In addition, the results indicated that language proficiency had significant effects on CS preferences of ELT students. Overall, elementary students were significantly different from other language proficiencies. The findings support Rezaee and Fathi's (2017). The reason for such a difference across different proficiency levels may be rooted in the amount of support from L1 that elementary students need to comprehend the ELT specialized materials. As command of English improves, ELT Students can comprehend technicalities of their major and hence rely less on the L1 mediating role. Besides gender, age, and proficiency, educational level of ELT students and its role in the amount of CS exploitation was investigated. The results showed that the educational levels (Bachelor's, Master's \& Doctorate's students) had diverse attitudes toward overall code switching use. The results of Tukey HSD test showed Bachelors' were significantly different from other educational levels in their overall CS preferences. In line with Liu (2010), there seems to be an interwoven link between the level of education, language proficiency and CS preferences. Put it differently, because at the B.A level, ELT students are less familiar with specialized terms, concepts and technicalities, although might be highly proficient, L1 acts like a catalyst that ingrains the basics in the mind of ELT students. As they progress to higher educational levels, their background and basic knowledge as well as their command of English might help them comprehend advanced issues of the discipline faster and easier. Finally, based on the findings of the second research question, the most and the least important factors of the ELT attitude questionnaire were a tool for augmenting understanding and barriers for communication, respectively. If we dig into the most and the least significant factors of CS, it can be realized that both point out to the same idea that CS can be quite promising for making the complex ideas and concepts which are difficult to be understood by ELT students simplified.

\section{Conclusion}

This study intended to develop a model of limitations and benefits of code switching from the perspectives of undergraduate and postgraduate EFL learners. The findings of this study are according to the post method suggestions which is peculiarity of the context. In this the study, all the methodological steps such as EFA, CFA, and SEM were followed. Therefore, SEM procedures indicated a meaningful relationship between the latent variables. This inquiry linked a concept that was most often discussed in EFL classrooms to the discipline of TEFL in the Iranian context by validating a CS scale in terms of a quantitative model. The most important advantage of the scale is that it was flourished and paved its way 
in a setting which, as far as the researchers are concerned had few or no context-bound CS scales. The scale has gone through sophisticated methodological analyses to be shaped in the present form. The model presented in the form of a CS scale in comparison to the existing models is well-organized, comprehensive, and easy to follow and understand. As a matter of fact, the model is comprehensive and ameliorates the earlier models in terms of their general taste. Unlike Rose and Dulms' (2007) model developed for universal audiences, the presented model addressed Iranian ELT undergraduate and postgraduate needs in the context of Iran.

In addition, the model has improvements over the earlier model of code switching and has added affective and rapport building components to the model. However, the scale and the SEM output in terms of a quantitative model is at its incipient stage and needs to be checked in ELT courses to be contextually evaluated in order for its shortcomings to be spotted and addressed in follow-up studies. Besides that, the factors of the scale were presented according to the order of significance and the researchers attached the demographic variables of gender, age, educational level and language proficiency and checked the appropriateness of CS with a large number of ELT candidates in Iran. Findings of the demographic variables in this study can help teachers to guide students properly to achieve their goals in an educational setting. Teachers also can support students not only to internalize course content, but also to develop learning strategies according to students' differences. In fact, the study was limited in that the results were based on the students' self-report especially related to some of the socio-demographic factors like language proficiency. In addition, the data collection was conducted through the medium of electronic devices made it impossible to address any misunderstanding and questions regarding the statements of the questionnaire, moreover, the convenience sampling is also a limitation as this kind of sampling leaves out participants from diverse backgrounds.

This study can have implications for ELT teachers that a comprehensive presentation of information can be achieved by including CS when necessary. Also, CS may remind ELT teachers that we are not only instructors inside the classroom, we have to create passion, rapport and enthusiasm inside and outside our classes. As a result, CS can create a friendly atmosphere which makes learning last longer. Moreover, CS can create a secure environment that can affect leaners' achievements. On the other hand, teachers also should be aware of the pros and cons of code switching in order to use/ avoid it wisely. Finally, it is of paramount importance to make conditions to use and examine this model in the real context of ELT classrooms in order to spot its deficiencies and promote its applicability. Consequently, future studies can focus on intervention and experimental studies to appraise the factors of the model inside the ELT classes and receive feedback on their applicability.

In addition, from the field of educational psychology it has been repeatedly proved that language learners are better in a non-threatening place that maximizes the learning potentials and minimizes the stress and anxiety among ELT students.

Conflict of interest: The authors state no conflict of interest in the study. 
Financial sponsor: The authors acknowledge that they have not received any financial support for all stages of the study, writing and publication of the paper.

\section{References}

Adelheid, A. N., \& Penny, M. P. (2012). Presenting Your Findings: A Practical Guide for Creating Tables. Washington, DC: American Psychological Association.

Adendroff, R. (1993). Code-switching amongst Zulu-speaking teachers and their pupils: Its functions and implications for teacher education. Southern African Journal of Applied Language Studies 2(1), 3-26.

Ahmad, B. A. \&Jusoff, K. (2009). Teachers' code-switching in classroom instructions for low English proficient learners. English LanguageTeaching Journal, Vol 2(2), 49-55.

Alenezi, M. (2016). Gender and Students' Perspective toward Code-Switching: A Correlational Study with Reference to Saudi Arabian Medical Students at Northern Boarder . International Journal of English Language \& Translation Studies.4(3), 154-166.

Al, Hawazen. (2012). Code switching between Arabic and English, social motivations and structural constraints (Unpublished PhD Dissertation) Ball State University: Indiana, USA.

Arthur, J. (2001). Code-switching and collusion: Classroom interaction in Botswana primary schools . Voices of authority: Education and Linguistic Difference, 57-75.

Auer, Peter, ed. (2013). Code-switching in Conversation: Language, Interaction and Identity.

Routledge: New York.

Azlan, N.M.N.I.\& Narasuman, S. (2013). The role of code-switching as a communicative tool in an ESL teacher education classroom. Procedia -Social and Behavioral Sciences, 90, 458 - 467.

Bartlett, M. S. ( 1954). A note on the multiplying factors for various chi square approximation. Journal of Royal Statistical Society, 16(Series B), 296-8.

Bentler, P. M. (1990). Comparative fit indexes in structuralmodels. Psychological Bulletin, 107, 238246.

Bolander, I. (2008). Code-switching in the classroom. A sign of deficiency or a part of the learning process? Sweden: Gutenberg, Karlstads Universities. .

Brown, K. (2006). Encyclopedia of language and linguistics. Oxford: Elsevier.

Bullock, B. E., \& Toribio, A. J. (2009). The Cambridge handbook of linguistic code-switching. New York, NY: Cambridge University Press.

Burton, L. J. and Mazerolle, S. (2011). Survey Instrument Validity Part I: Principles of Survey Instrument Development and Validation in Athletic Training Education Research. Athletic Training Education Journal, 6, 27-35.

Comery, A. L. and H. B. Lee . (1992). A First Course in Factor Analysis. Hillsdale, NJ:Erlbaum. 
Ding, L., Velicer, W. F., \& Harlow, L. L. (1995). Effects of estimation methods, number of indicators per factor, and improper solutions on structural equation modeling fit indices. Structural Equation Modeling: A Multidisciplinary Journal, 2(2), 119-143. .

Enama, P. R. (2016). The impact of English-only and bilingual approaches to EFL instruction on lowachieving bilinguals in Cameroon: An empirical study. Journal of Language Teaching and Research, 7(1), 19-30.

Ferguson, G. (2003). Classroom code-switching in post-colonial contexts Functions, attitudes and policies in Makoni, S. and Meinhof, U. African and Applied Linguistics. AILA Volume Review Volume 16. Amsterdam: John Benjamins.

Cheshire, J. a. G.-C., P. (1998). Code-switching and the sociolinguistic gender pattern International Journal of the Sociology of Language Vol. 129, 5-34.

Cook, V. (2001). Using the first language in the classroom. Canadian Modern Language Review, 57(3), 402-423.

Grobler, R. (2018). Students' Perceptions of Code-Switching in Natural Sciences Classrooms: A South African Perspective. Africa Education Review, 15(1), 38-51.

Heredia, Roberto R. \& Brown, Jeffrey M. (2005). Code-Switching. Texas A \& M International University. In Strazny, Philipp (Ed.)The Encyclopedia of Linguistics. New York, Fitzroy Dearborn, Taylor \& Francis Group, USA.: USA.

Hobbs, V., Matsuo, A., \& Payne, M. (2010). Code-switching practice in Japanese language classroom: An exploratory investigation of native vs. Non-native speaker teacher practice . Linguistic and Education, 44-59.

Hoe, S. L. (2008). Issues and Procedures in Adopting Structural Equation Modeling Technique . Jounal of Applied Quantitative Methods 3, 76-83.

Hussein, R. F. (1999). Code-Alteration among Arab College Students. World Englishes, 18(2), 281-289.

Javier, R.A., Marcos, L.R. The role of stress on the language-independence and code-switching phenomena. J Psycholinguist Res 18, 449-472 (1989). https://doi.org/10.1007/BF01067310

Kenny, D.A., Kaniskan,B.and McCoach,D. B . (2014). The performance of RMSEA in models with small degrees of freedom. Sociological Methods \& Research, .

Liebscher, G., \& Dailey-O ${ }^{\text {ee }}$ Cain. (2005). Learner code switching in the content-based foreign language classroom. The Modern Language Journal, 89, 234-247. doi 10.1111/j.15404781.2005.00277.x/pdf Lucaz.

Lin, A. M. (2013). Multilingual and multimodal resources in L2 English content classrooms. In C. Leung \& B. Street (Eds.), English: A changingmedium for education,(pp. 79-103). Bristol: Multilingual Matters.

Liu, J.X., 2010. Teachers' code-switching to the L1 in EFL classroom. The Open Applied Linguistics Journal, 3: 10-23 
Modupeola, R. O. (2013). Code- Switching as a teaching strategy: Implication for English Language teaching and learning in a multilingual society. IOSR Journal of Humanities and Social Science (IOSR-JHSS), 14(3), 92-94.

Mohammadi Salari, Z., Samimi, F., \& Afraz, Sh. (2019). A Qualitative Inquiry into Perceptions and Practices of High and Low EFL Achievers towards the Limitations and Benefits of Code Switching. Journal of Teaching Language Skills, (JTLS), 37(4), 109-139.

Momenian, M.,\& Samar, R. G. (2011). Functions of CS among Iranian advanced and elementary teachers and students. Educational Research and Reviews, 6(13), 769-777.

Moradkhani, S. (2012). The typology of EFL teachers' code switching: A validation study. The Journal of Teaching Language Skills, 4(3), 103-126. .

Myers-Scotton, C. (1993). Social motivations for code-switching: Evidence fromAfrica. Oxford: Clarendon Press.

Nordin, N. M., Ali, F. D. R., Zubir, S. I. S. S., \& Sadjirin, R. (2013). ESL learners'reactions towards code-switching in classroom settings. Procedia-Social and Behavioral Sciences, 90, 478-487.

Pallant, J. (2007). SPSS Survivalmanual: A Step By Step Guide to data analysis using SPSS. Allen \& Unwin, Sabon by Bookhouse, Sydney.

Pallant, J. (2010). SPSS survival manual. 4th.England: McGraw-Hill Education.

Peregoy, S. F., \& Boyle, O. F. (2013). Reading, writing and learning in ESL: A resource book for teaching K-12 English learners (6th ed.). . Boston, US: Pearson.

Qian X, Tian G, and Wang Q . (2009). Codeswitching in the primary EFL classroom in China: Two case studies . System 37(4), 719-30.

Rahimi, A., \& Jafari, Z. (2011). Iranian students' attitudes towards the facilitative and debilitative role of code-switching: Types and moments of code-switching at EFL classrooms. The Buckingham Journal of Language and Linguistics, 4, 15-28.

Rasouli \& Shahla, S. (2015). Teachers and students' perceptions of code switching in aviation language learning courses. International Journal of Research Studies in Language Learning, 5(3), 3-18.

Rezaee, A. A., \& Fathi, S. (2017). The Perceptions of Language Learners across Various Proficiency Levels of Teachers' Code-switching. Issues in Language Teaching, 5(2), 254-233.

Rose, S. \& O. Van Dulm. (2007 ). Functions of code-switching in multilingual classrooms. Per Linguam $22(2), 1-13$.

Samar G. Reza \&Shahab Moradkhani. (2014). Code-switching in the language classroom: A study of four EFL teacherscognition. RELC Journal, 45(2), 151-164.

Schermelleh-Engel, K., \& Moosbrugger, H. (2003). Evaluating the fit of structural equation models: Tests of significance and descriptive goodness-of-fit measures. Methods of Psychological Research Online, 8(2), 23-74.

Shin, Y. (2010). The functions of Code-switching in a Korean Sunday School. Heritage Language Journal 7(1), 91-116. 
Schumacker, R. Lomax, R. . (2004). A Beginner's Guide to Structural Equation Modeling 2nd Ed. Mahwah, NJ: Lawrence Erlbaum.

Sebba, M. (2012). Researching and Theorizing Multilingual Texts. In S. Mark, M. Shahrzad \& J. Carla (Eds.), Language Mixing and Code-Switching in Writing: Approaches to Mixed-Language Written Discourse. New York: Roultedge. https://doi.org/10.4324/9780203136133

Sert, O. (2005). The Functions of Code-Switching in ELT Classrooms. Online Submission, 11(8).

Setati, M., J. Adler, Y. Reed and A. Bapoo. (2002). Incomplete journeys: Code-switching and other language practices in mathematics, science and English language classrooms in South Africa. Language and Education 16(2), 128-149.

Sugawara, H. M., \& MacCallum, R. C. (1993). Effect of estimation method on incremental fit indexes for covariance structure models. Applied Psychological Measurement, 17(4),365-377.

Sumartono, Firqin \& Tan Ying Ying. (2018). Juggling Two Languages: Malay-English Bilinguals' Codeswitching Behaviour in Singapore. The Linguistics Journal 12(1), 108-138.

Tabanick, B. G., \& Fidell, L. S. (2007). Using Multivariate Statistics (5th ed.). New York: Allyn and Bacon.

Vogt, Hans. (1954). “Language Contacts.” Word 10(2-3): 365-374.

Walden, U. (2012). Educational social psychology. www.experiment-reserch. com, www.alleydog.com $1998-2012$.

Wardhaugh, R. (2006). An introduction to sociolinguistics $\left(5^{\text {th }}\right.$ ed.). New York:

Blackwell Publishing

Wei, L. \& Martin, P.,. (2009). Conflicts and tensions in codeswitching in a Taiwanese EFL classroom. International Journal of Bilingual Education and Bilingualism. [e-journal] 12 (2), 117-122. 